\title{
Identification of the Triticoid-type grains (Poaceae) from archaeobotanical assemblages in southwest Asia as Heteranthelium piliferum (Banks \& Sol.) Hochst.
}

\author{
Alexander Weide ${ }^{1,2}$ (D) Amaia Arranz-Otaegui ${ }^{3} \cdot$ Ann Frijda Schmidt $^{3} \cdot$ Hyunyoung Kim $^{1} \cdot$ Michael Charles $^{1} \cdot$ \\ Mohsen Zeidi ${ }^{4,5} \cdot$ Hojjat Darabi $^{6} \cdot$ Tobias Richter $^{3} \cdot$ Nicholas J. Conard $^{4,5}$
}

Received: 31 May 2020 / Accepted: 16 December 2020 / Published online: 22 January 2021

(c) The Author(s) 2021

\begin{abstract}
The so-called Triticoid-type grains are known from several prehistoric sites in southwest Asia and their identification has long been unclear. They resemble the grains of wheats and researchers suggested they may represent an extinct Triticeae species, possibly closely related to wild crop progenitors. In this study we identify the Triticoid-type grains as Heteranthelium piliferum (Banks \& Sol.) Hochst. and describe the key identification criteria. The identification is based on morphological analyses of modern and archaeological material from several grass species and was first achieved with well-preserved specimens from Early Neolithic Chogha Golan, Iran. We further examined the Triticoid-type grains from recently excavated samples from Early Neolithic Ganj Dareh, Iran, and archived samples from Late Chalcolithic and Late Bronze Age Tell Brak in northeast Syria, confirming their identification as H. piliferum. Based on the study of herbarium specimens at Royal Botanic Gardens Kew, London, we provide a detailed distribution map and review the species' biology and ecological adaptations. Collected and cultivated herbarium specimens were analysed in order to understand the high phenotypic plasticity of the growth habit, its correlation with environmental variables and its relation to grain size. In order to understand the high morphological variability of the charred Triticoid-type grains from archaeological deposits, we assessed the effects of experimental carbonisation at different temperatures on grains of $H$. piliferum, Triticum dicoccum, T. thaoudar and Secale vavilovii. In light of the present study, we discuss the relevance of $H$. piliferum for reconstructing prehistoric subsistence strategies.
\end{abstract}

Keywords Near East · Neolithic $\cdot$ Wild grass $\cdot$ Arable weed $\cdot$ Grain size $\cdot$ Carbonisation

Communicated by A. Fairbairn.

Supplementary Information The online version of this article (https://doi.org/10.1007/s00334-020-00822-x) contains supplementary material, which is available to authorized users.

Alexander Weide

alexander.weide@arch.ox.ac.uk

1 School of Archaeology, University of Oxford, 1 South Parks Road, Oxford OX1 3TG, UK

2 Institute for Archaeological Sciences, University of Tübingen, Rümelinstr. 23, 72070 Tübingen, Germany

3 Centre for the Study of Early Agricultural Societies, University of Copenhagen, Karen Blixens vej 4, Building 10, 2300 Copenhagen, Denmark

\section{Introduction}

Willem van Zeist and colleagues described an unidentified Poaceae grain type in their archaeobotanical report from the Early Neolithic site of Ganj Dareh in the central Zagros Mountains of Iran (van Zeist et al. 1984). Due to its morphological similarity to species of the tribe Triticeae, they

4 Department of Early Prehistory and Quaternary Ecology, University of Tübingen, Schloß Hohentübingen, Burgsteige 11, 72070 Tübingen, Germany

5 Senckenberg Center for Human Evolution and Palaeoenvironment, University of Tübingen, Rümelinstr. 23, 72070 Tübingen, Germany

6 Department of Archaeology, Razi University, Kermanshah, Iran 
referred to the unidentified grains as 'Triticoid type' (van Zeist et al. 1984, p. 212). The authors speculated whether more than one species could be represented by these grains, given their large variability in size and shape. The second published record derives from Early Dynastic layers at Tell Bderi in northeast Syria, dating to the 3rd millennium BC (van Zeist 1999/2000). Savard et al. (2003) mentioned some grains resembling the Triticoid-types in the assemblage from Early Neolithic M'lefaat in northern Iraq, which they included in a Triticum boeoticum/Secale category. Riehl et al. $(2012,2013)$ documented Triticoid-type grains from the Early Neolithic sites of East Chia Sabz and Chogha Golan in the central Zagros region of Iran, where this grain type is now reported at a cluster of sites dating from the early 10th to the early 7 th millennia BC.

The fact that the Triticoid-type grains remained unidentified is unsatisfactory for several reasons. As different authors emphasised, they clearly resemble Triticeae taxa and can easily be confused with grains of wild or domestic einkorn, rye or even emmer (Savard et al. 2003; Riehl et al. 2013). Their concentration at three, probably four, Early Neolithic sites in the eastern arc of the Fertile Crescent is particularly puzzling and authors hypothesised whether they represent a local variety of a wild wheat progenitor or a separate species that is now extinct (Riehl et al. 2013), while Kenéz et al. (2014) suggested Dasypyrum villosum as a possible candidate. Moreover, our understanding of the ecological and potential economic significance of the species represented by the Triticoid-type grains in prehistoric subsistence strategies remains limited if we cannot reconstruct its growing habit and modern ecological niche. This is of particular interest for Early Neolithic sites in northern Iraq and western Iran, as archaeobotanical data indicate that a diverse complex of wild grasses played an important role in local subsistence practices (Savard et al. 2006; Weide et al. 2018; Whitlam et al. 2018).

Here we identify the Triticoid-type grains as Heteranthelium piliferum (Banks \& Sol.) Hochst. and describe the key identification criteria for this Triticeae species. The identification is based on morphological analyses of modern and archaeological material from several grass species and was first achieved with well-preserved specimens from Chogha Golan. We further examined Triticoid-type grains from recently excavated samples from Early Neolithic Ganj Dareh (Darabi et al. 2019) and archived samples from Tell Brak in northeast Syria, dating from the Late Chalcolithic to the Late Bronze Age (McMahon et al. 2007; Hald 2008), which confirmed their identification as $H$. piliferum. We provide a detailed distribution map of $H$. piliferum, based on the study of herbarium specimens at Royal Botanic Gardens Kew, London, and review the species' biology and ecological adaptations. Collected and cultivated herbarium specimens were analysed in order to understand the high phenotypic plasticity of the growth habit, its correlation with environmental variables and its relation to grain size. Theoretically, increased growth rates should be correlated with enhanced growing conditions (Sugiyama and Bazzaz 1998; Lutman et al. 2011), so variability in grain size might also give insights into the palaeoecology of $H$. piliferum. In order to understand the high morphological variability of the charred Triticoid-type grains from archaeological deposits and their similarity to other Triticeae species, we assessed the effects of experimental carbonisation at different temperatures on grains of $H$. piliferum, Triticum dicoccum, $T$. thaoudar and Secale vavilovii (see ESM 1 Table 1 for a note on taxonomy). The goal of these charring experiments was to evaluate how the grains of these species respond to heat and to determine at which temperature $H$. piliferum grains become indistinguishable from the other taxa. Considering the results of the present study, we discuss the relevance of $H$. piliferum for reconstructing prehistoric subsistence strategies.

\section{Heteranthelium piliferum (Banks \& Sol.) Hochst.}

Heteranthelium is a monotypic genus within the tribe Triticeae with only one annual species $H$. piliferum. Synonyms include Elymus pilifer Banks \& Sol. (=basionym), Agropyron piliferum (Sol.) Benth. ex Aitch., Eremopyrum olgae (Regel) P. Candargy, Heteranthelium aleppicum Gand., $H$. assyriacum Gand. and H. hermoneum Gand. (WCSP 2020). Based on hybridisation experiments, Sakamoto (1974) expected $H$. piliferum to form a distinct taxonomic entity within the Triticeae, which departed from other clades during a process of adaptation to relatively dry environments. These limited insights into the species' phylogeny were recently complemented by more detailed genetic analyses. Hodge et al. (2010) analysed relationships within the Triticeae using one chloroplast gene and found the taxon to cluster with Triticum monococcum, Secale cereale and all Aegilops species involved in the study. Escobar et al. (2011) broadly confirmed this pattern in their comprehensive study involving one chloroplast and 26 nuclear genes. Their results suggest that $H$. piliferum groups sister to a clade including $T$. monococcum, $S$. cereale, Taeniatherum caput-medusae and all analysed Aegilops species. This complex, also including Dasypyrum villosum, seem to have evolved in a reticulated manner due to a series of introgressive events. The close relationship of $\mathrm{H}$. piliferum to wheat and rye species explains why their grain morphologies are so similar.

As a winter annual, $H$. piliferum has a short flowering period of ca 2 month around April-May (Feinbrun-Dothan 1986). It is a short grass with a distinct spike morphology, reaching a maximum plant height of ca. $25-30 \mathrm{~cm}$, but often 
not more than 5-10 cm (Bor 1970; Feinbrun-Dothan 1986). Figure 1 illustrates the typical habit of the species with erect and decumbent culms. The relatively short spikes are composed of spikelets with two awn-like glumes, two or more fertile florets at the base and rudimentary sterile florets towards the apex (Fig. 2). The lemmas of the basal florets are distinctively tuberculate, which is a rare feature among Triticeae taxa. The lower fertile florets produce relatively large and elongated grains, whereas grains from the upper fertile florets are significantly smaller and shorter, contributing to the observed variability in grain size and shape (Fig. 2b).

Modern populations are known from Jordan, Palestine, Israel, Lebanon, Syria, Turkey, Iraq, Iran, Afghanistan, Pakistan, Uzbekistan and Kyrgyzstan (Fig. 3a). The species' distribution in southwest Asia mirrors a belt that receives between 250 and $750 \mathrm{~mm}$ annual precipitation, known as the Fertile Crescent, and follows this rainfall zone into areas of central Asia (Fig. 3b). The lowest collection sites at below $100 \mathrm{~m}$ a.s.l. are found in the northern Mesopotamian plain in Iraq and the species climbs to elevations of about 2,000 m a.s.l. in the Levantine Anti-Lebanon Mountains and the Zagros and Alborz Mountains in Iran. The highest known collection site at ca 2,700 m a.s.l. is located near Gardez in eastern Afghanistan. Some labels of herbarium vouchers at Royal Botanic Gardens Kew (ESM 1 Table 2) give more information about the collection sites, indicating that $H$. piliferum grows on a variety of clay and sandy soils, often on limestone and shale. Dry rocky hilltops and steep slopes represent a main habitat in which the species thrives today, however, H. piliferum also occurs in lowland steppes in northern Iraq, southeast Anatolia and the Levant (Russi et al. 1992; Abu-Zanat et al. 1998), and oak-dominated woodlands in the Zagros Mountains (Heydari et al. 2013; Pourbabae et al. 2014). The species seems to be well adapted to a variety of semi-arid habitats and grows in disturbed places, along roadsides and as an arable weed in wheat and barley fields. Malekpour (1975) lists H. piliferum among a complex of annual grasses in central Iranian rangelands, which he principally considers as weeds that are highly adapted to disturbed environments.

Only a few labels of the recorded herbarium vouchers mention an association of $H$. piliferum with other species, including Stipa capensis, Aegilops spp. and wild Hordeum spp. Further insights into the species' associations and adaptations to drought and herbivory derive from published vegetation surveys which recorded $H$. piliferum.

Abu-Zanat et al. (1998) investigated the soil seed bank at four sites in western Jordanian grasslands that were subjected to uncontrolled grazing by sheep and goats. Although they do not report the stocking density and did not compare their results to control plots, they consider the investigated sites as representative of relatively high grazing pressures that lower species diversity and cause soil degradation.
Mean annual precipitation at the sites ranges between 250 and $450 \mathrm{~mm}$ at elevations from 380 to $950 \mathrm{~m}$ a.s.l. H. piliferum was present at all four sites and occurred in 50-90\% of the surveyed plots at three sites. The associated vegetation was dominated by the annual grasses Bromus lanceolatus, Lophochloa pumila, Lolium multiflorum, Nardurus maritimus and Poa bulbosa, and small-seeded annual legume species of the genera Astragalus, Medicago, Onobrychis, Trifolium and Trigonella. As $\mathrm{H}$. piliferum also dominated the soil seed bank, together with a few other Poaceae and Fabaceae species, the authors concluded that it is well adapted to high grazing pressures. Moreover, the authors collected caprine dung pellets from the soil samples, which contained seeds that were dominated by either Poaceae or Fabaceae species. Unfortunately, they did not report which species were present in the analysed pellets.

Russi et al. (1992) found contrasting patterns in the response of $H$. piliferum to increased grazing pressures by sheep in their study of Mediterranean grasslands near Aleppo in northwest Syria. The study region receives ca. $340 \mathrm{~mm}$ rainfall per year at an elevation of $284 \mathrm{~m}$ a.s.l. In the studied fields, $H$. piliferum belonged to the most common grasses and was associated with several species of Avena, Bromus and Trifolium. The authors analysed the composition and development of the soil seed bank over three vegetation seasons between fields with grazing pressures of 0.8 and 1.7 to sheep/ha, respectively. In the last year, the stocking rates were increased to 1.1 and 2.3 sheep/ha, respectively, which was below the regional mean stocking rate of 4.14 sheep/ha. These minor differences still had effects on several species, including $H$. piliferum, whose contribution to the soil seed bank under increased grazing pressures showed the most pronounced decline among all species. Ca. $41 \%$ of its total seed set was lost during summer, which the authors mainly attributed to grazing. This may be taken as an indicator that $H$. piliferum seeds would not regularly survive ruminant digestion, as we would expect given the lack of a hard seed enclosure and the larger size compared to seeds that survive ruminant digestion (Valamoti and Charles 2005; Wallace and Charles 2013). However, there seem to be unknown factors that allowed $H$. piliferum to dominate the vegetation cover and soil seed bank in overgrazed Jordanian grasslands, so the two studies are not fully conclusive regarding the species' adaptation to herbivory. In general terms, its life history (short lived/annual), morphology (short grass) and colonisation ability (ruderal, colonises gaps) should make it well adapted to grazing (Lavorel et al. 1997; Bullock et al. 2001).

Pourbabae et al. (2014) investigated the response of understorey vegetation in a Zagrosian oak forest to a local drought event in 2008. The area, located at ca. $1,850 \mathrm{~m}$ a.s.l., receives ca. $400 \mathrm{~mm}$ of rainfall per year, while the drought year only received ca. $220 \mathrm{~mm}$. Throughout three consecutive years, including the drought year, $H$. piliferum showed 

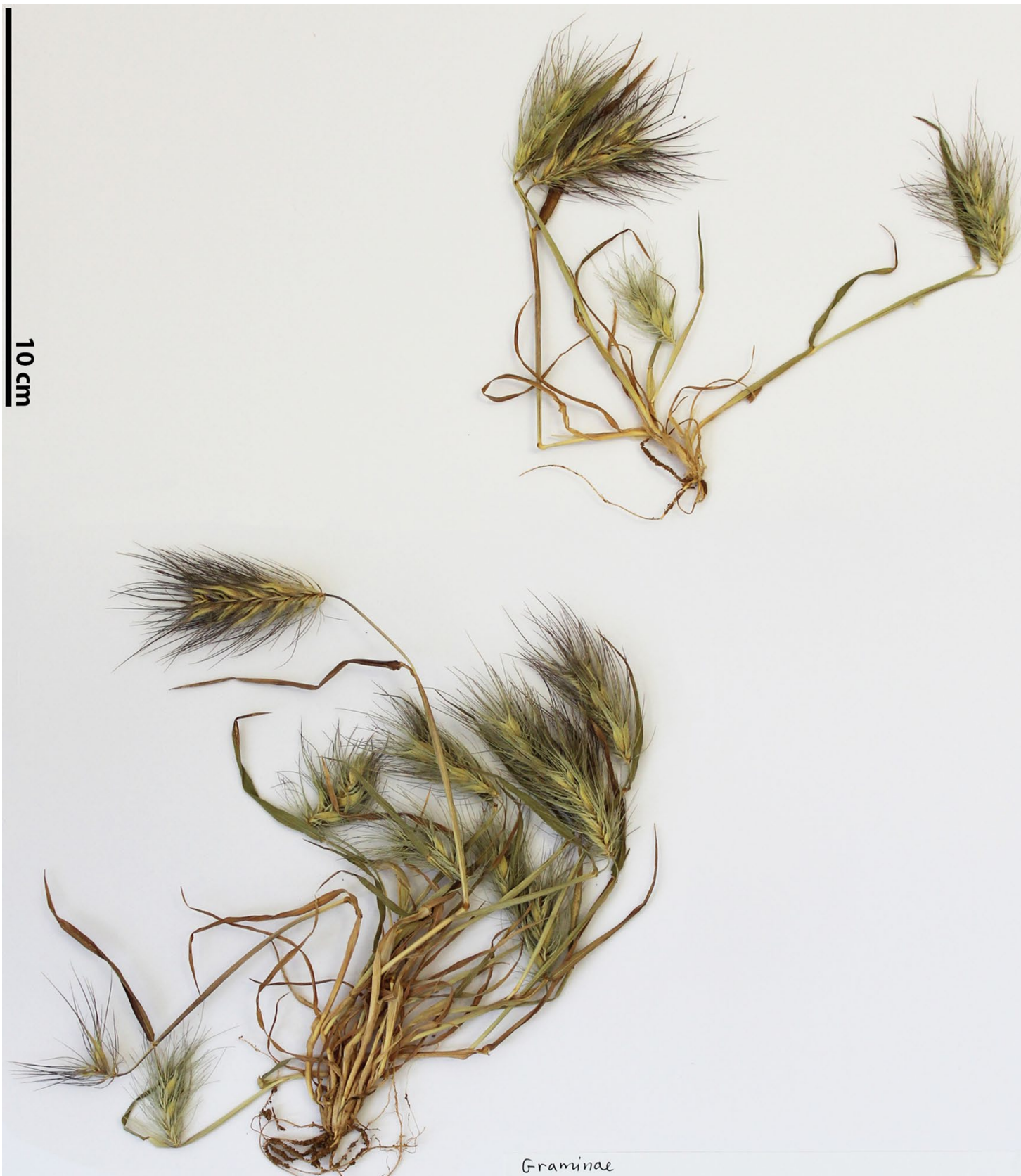

Graminae

עשבית האוניברסיטה העברית בירושלים

HERBARIUM UNIVERSITATIS HEBRAÏCAE HIEROSOLYMITANAE

FLORA PALAESTINA צמחית ארץ-ישראל

Name Heteranthelium piliferum (Sol.) Hochst.

Loc\& Hab. Hermon, Yifát Ridge s'terpo

The National Herbarium

Hebrew University Jerusalem

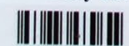

HUJ $h 131228$

Tested and Computerized: 2015

$\begin{array}{lll}\text { Alt. } & \text { Leg. S. Cohen-Sivan } \\ \text { Dat. } 14 \text { June 2011 האריד } & \text { Det. }\end{array}$

Fig. 1 Habit of H. piliferum (HUJHERB 131228) 


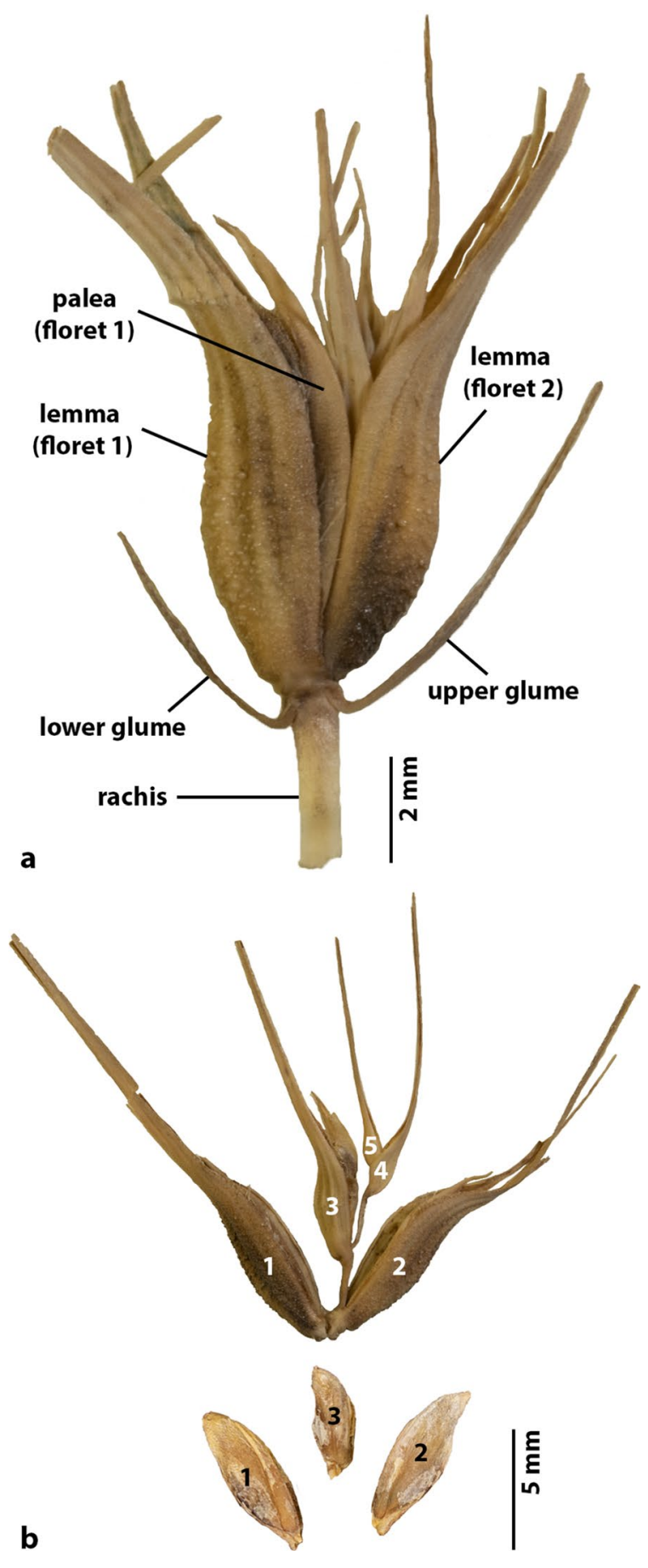

Fig. 2 a Spikelet of $H$. piliferum; $\mathbf{b}$ unfolded spikelet with five florets and three developed grains (numbers indicate single florets and their corresponding grains)

no response in ground cover and biomass production, while both values increased or decreased with the drought event for most other species (86\%). This is not surprising, as the species' distribution also covers marginal areas that may receive less than $250 \mathrm{~mm}$ rainfall in some years (Fig. 3b). In this more closed woodland habitat, $H$. piliferum was not among the species with the highest contribution to ground cover, which included mostly perennials such as Euphorbia aucheri (Euphorbiaceae), Phlomis kurdica (Lamiaceae), Ferula haussknechtii (Apiaceae), Gundelia tournefortii and Eryngium caucasicum (Asteraceae).

\section{Material and methods}

The morphology of the charred Triticoid-type grains from Chogha Golan was examined at the Institute for Archaeological Sciences, University of Tübingen, with a binocular light microscope with 10 to $60 \times$ magnifications. Their identification as $H$. piliferum was confirmed with modern reference material from Israel, Iran and Uzbekistan, provided by the Israel Gene Bank and the Gene Bank of the Crop Research Institute Prague. Charred archaeological specimens from Ganj Dareh and Tell Brak were examined using binocular light microscopes at the Centre for the Study of Early Agricultural Societies, University of Copenhagen, and the School of Archaeology, University of Oxford, respectively. In order to obtain a representative number of Triticoid-type grains from each archaeological site, samples were screened for complete grains and a total of 116 specimens were selected for analysis and photographed with digital microscopes. ESM 1 Table 2 gives information about all archaeological and modern specimens examined for this study, including their provenance and/or stratigraphic context. Hereafter, we use the term 'Triticoid-type' for grains from archaeological deposits, which always refers to its identification as $H$. piliferum.

Loose H. piliferum grains from modern herbarium specimens and modern grains from comparative collections and gene banks were examined and photographed with digital microscopes at the Israel National Herbarium of the Hebrew University of Jerusalem, the Archaeobotany Laboratory at the Bar-Ilan University of Ramat Gan, the Institute of Archaeology at University College London (UCL) and Royal Botanic Gardens Kew, London. Dimensions of modern and archaeological grains (ESM 2) were measured digitally at the School of Archaeology, University of Oxford, and at the Centre for the Study of Early Agricultural Societies, University of Copenhagen, using ImageJ version $1.52 \mathrm{a}$ (Schneider et al. 2012) and integrated measurement programs of the digital microscopes. Triticoid-type grain measurements obtained in this study were compared to published grains measurements from the Early Neolithic sites of Çayönü (Turkey), Mureybet, Tell Aswad and Tell Ramad (Syria) (van Zeist and Bakker-Heeres 1982, 1984; van Zeist and de Roller 1991/1992). SEM photographs were taken at the Senckenberg Center for Human Evolution and Palaeoenvironment, Eberhard Karls University of Tübingen. 
Fig. 3 a Origin of modern $H$. piliferum accessions, archaeological records and archaeological sites mentioned in the text; b mean annual precipitation based on Hijmans et al. (2005). Archaeological sites: (1) Chogha Golan; (2) East Chia Sabz; (3) Ganj Dareh; (4) M'lefaat (for presence of Triticoid-type grains please see text); (5) Tell Bderi; (6) Tell Brak; (7) Çayönü; (8) Mureybet; (9) Tell Aswad; (10) Tell Ramad. This distribution map is based on label information of herbarium vouchers stored at Royal Botanic Gardens Kew, London, studied accessions from different comparative collections and gene banks (ESM 1 Table 2) and occurrence records in the Global Biodiversity Information Facility (20 August 2019, GBIF occurrence download: https://doi.org/10.15468/ dl.mjauyh)
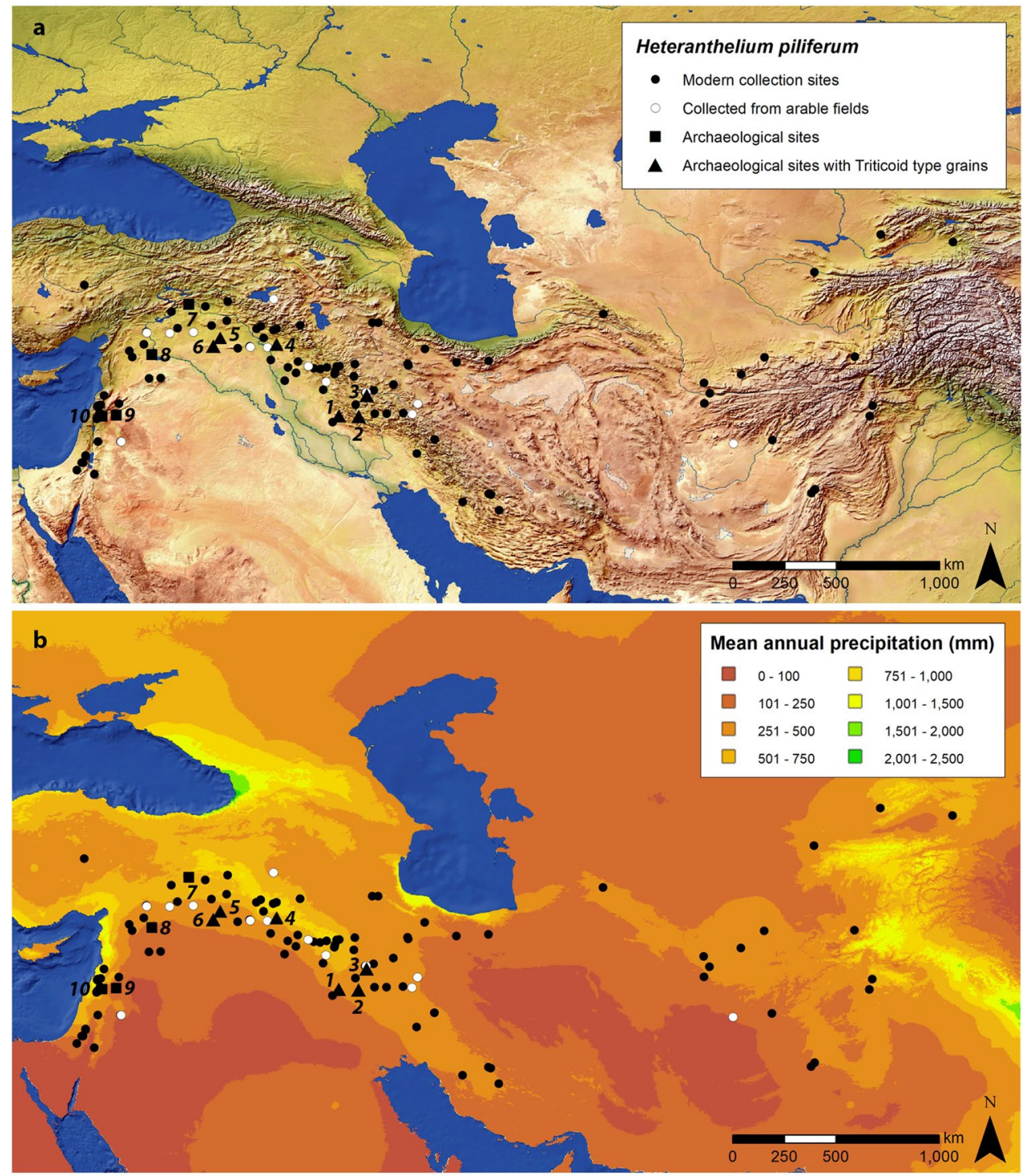

Maximum plant height of herbarium specimens could be measured at Royal Botanic Gardens Kew, including specimens that were cultivated under greenhouse conditions at the Plant Germplasm Institute at Kyoto University (ESM 1 Table 2). These cultivated specimens all derived from seed material collected by S. Sakamoto in Iraq during the 1960s and 1970s. Unfortunately, it was not possible to obtain detailed information about the specific growing conditions. Maximum plant height was measured from the lowest end of the culm to the upper tip of the highest spike. If one voucher carried more than one specimen, we took the mean value from all specimens that had roots. As $H$. piliferum is a relatively short grass, rarely exceeding $30 \mathrm{~cm}$, we do not expect a bias in plant height among specimens collected for herbarium vouchers. Culms of specimens cultivated under greenhouse conditions were bent to fit on vouchers, so maximum plant height could also be reliably measured in these cases. However, we could not quantify the number of tillers and spikes per plant, as most collected herbarium specimens did not represent a complete ramet.

All statistical analyses were performed with IBM SPSS Statistics version 25 . We experimentally charred modern grains of $H$. piliferum, $T$. dicoccum, $T$. thaoudar and $S$. vavilovii using a muffle furnace at the School of Archaeology, University of Oxford. Grains were put in glass crucibles and covered with sand to minimise oxygen supply during carbonisation. Between 5 to 10 grains were charred at three different temperatures $\left(230,260,300{ }^{\circ} \mathrm{C}\right)$ in a pre-heated oven for four $\mathrm{h}$ each. These temperatures overlap with and exceed the range of $220-240{ }^{\circ} \mathrm{C}$, in which experimentally charred glume wheat grains show the closest match to well preserved and only slightly distorted charred grains from archaeological deposits (Charles et al. 2015). 


\section{Results}

\section{Phenotypic plasticity of $H$. piliferum}

Individual specimens of $H$. piliferum vary considerably in size, which is expected for an annual grass. The smallest collected individuals barely reach a height of $5 \mathrm{~cm}$ from the base of the culm to the highest spike, while the tallest measured about $28 \mathrm{~cm}$. Cultivated individuals were much taller and developed more tillers (ESM 1 Fig. 1), although the number of tillers and spikes per plant could not be reliably quantified among herbarium specimens. This high variability in the growth habit indicates that environmental conditions have a pronounced effect on the species' performance and raises the question of which ecological variables are correlated with the observed phenotypic plasticity.

There was no correlation between plant height of the collected specimens and the altitude of the collection site (Spearman's rho, $\left.r_{\mathrm{s}}[57]=-0.241, p=0.066\right)$. Plants collected from arable fields $(N=17, M=180.9$, SD 64.5) were not significantly taller than plants collected from non-arable habitats $(N=55, M=156.4$, SD 55.4; t-test, $t(70)=-1.5, p=0.13)$. However, plants cultivated under greenhouse conditions ( $N=44, M=366.7$, SD 64.6) were significantly taller than plants collected from arable and non-arable habitats $(N=72, M=162.2$, SD 58.1; t-test, $t(114)=-17.6, p=<0.0001$; Fig. 4a). Scatter plots of grain dimensions from cultivated and collected plants expressed as breadth by thickness and length by thickness do not clearly differentiate between growing conditions (Fig. 4b, c). However, mean grain thickness of cultivated specimens $(N=49, M=1.63$, SD 0.3$)$ was significantly smaller than thickness of collected grains $(N=74$, $M=1.92$, SD 0.33; t-test, $t(121)=4.8, p=<0.0001)$. This is due to numerous 'flat' grains among the cultivated specimens. Variability in length among cultivated grains (3.5-5.7 mm, $M=5$ ) was significantly lower than among grains of collected individuals $(2.9-6.9 \mathrm{~mm}, M=5.1$; Levene's test, $F(1,121)=0.65, p=<0.0001)$.

\section{Morphological features for identifying the Triticoid-type grains and their response to experimental carbonisation}

The morphology of uncharred H. piliferum grains is very characteristic (Fig. 5), although the different florets induce some variability in grain size and shape (Fig. 2b). While the pointy grain shape in dorsal and ventral view resembles wild progenitor species such as einkorn, grain shape in lateral view cannot be confused with that of other species. In lateral view the grains are distinctively rhomboid

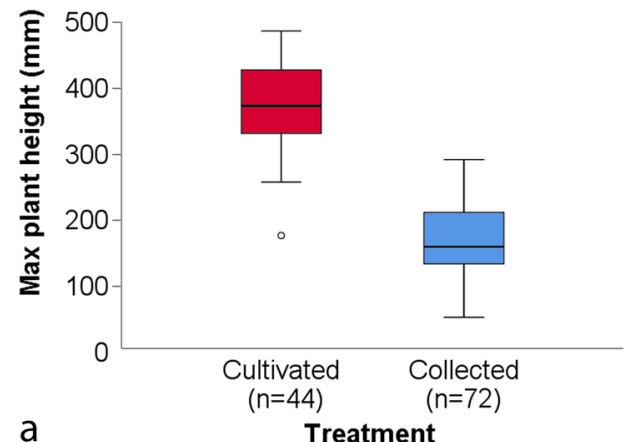

a

Treatment
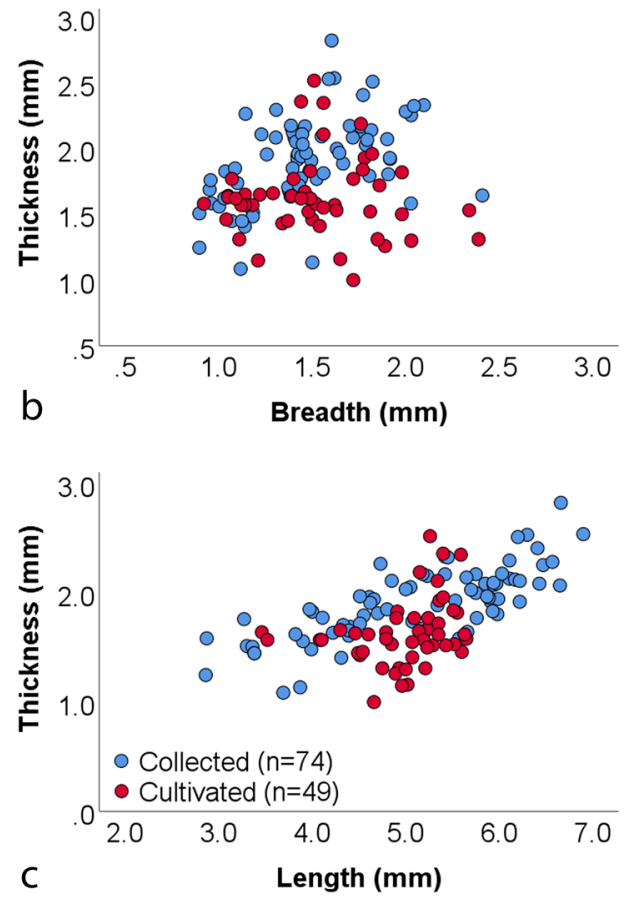

Fig. 4 a Difference in maximum plant height between a $H$. piliferum group cultivated under greenhouse conditions and collected specimens; b scatter plots show grain breadth by thickness and $\mathbf{c}$ grain length by thickness

with the ventral side describing a curve towards the apical end, forming a pointed apex. This appearance is similar between grains that are very narrow and were probably not fully ripe when collected (Fig. 5a-d) and fully developed grains with a round cross-section (Fig. 5e-h). An additional diagnostic feature of the grains is their lateral ridge, an impression caused by the margins of the enclosing lemma and palea. This ridge runs from the lower side of the embryo towards the apex, following the curved ventral side (Fig. $5 \mathrm{~g}-\mathrm{i}$ ). The grains of rye species and emmer wheat do not show a lateral ridge, while grains of two-grained wild einkorn can have a straight lateral ridge that might complicate an identification if grain shape after charring is not diagnostic anymore (ESM 1 Fig. 2). 

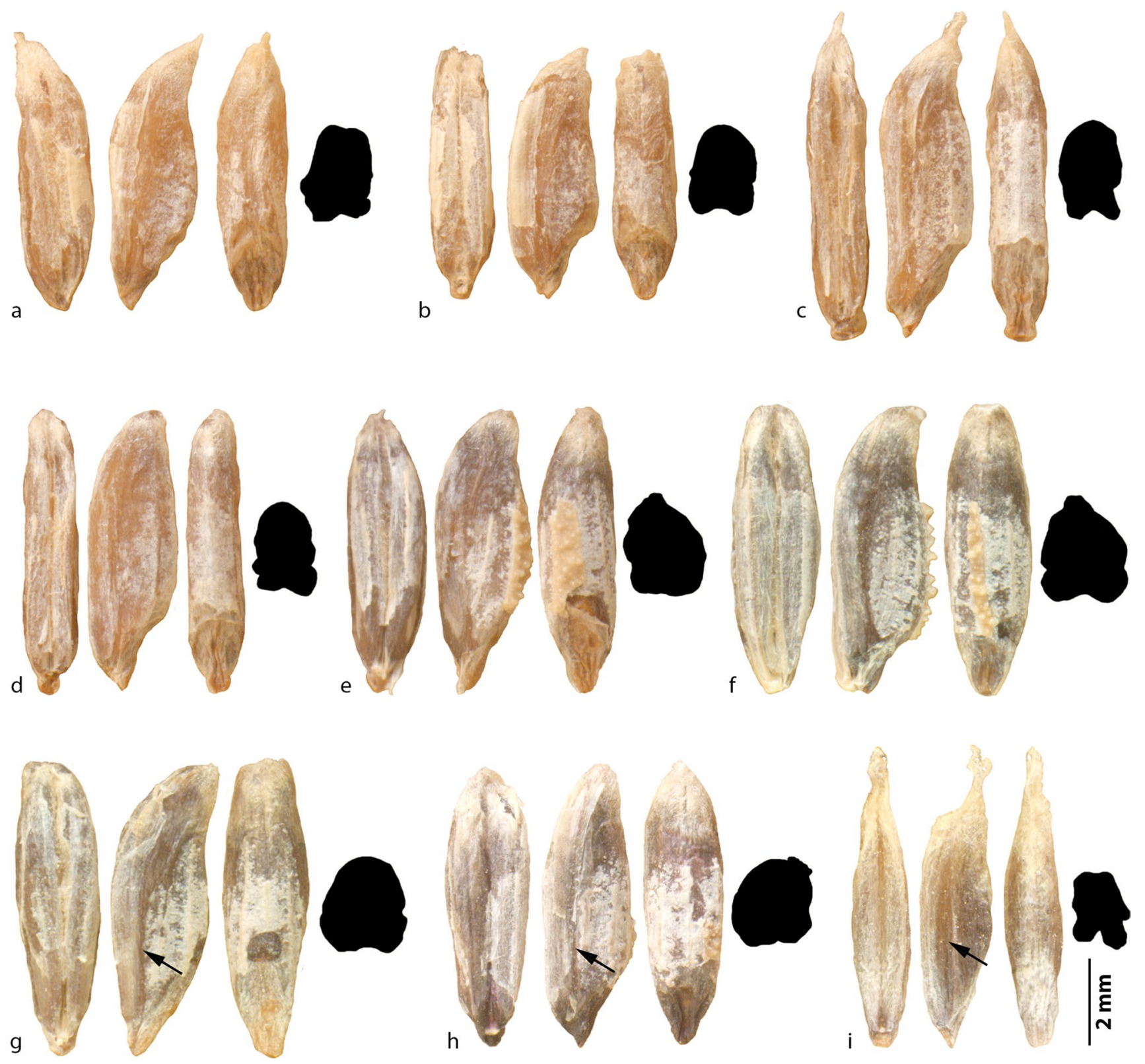

Fig. 5 Modern H. piliferum grains from Mt. Hermon (Comparative collection of the Archaeobotanical Laboratory, Bar-Ilan University of Ramat Gan, Israel). Note the rhomboid shape in lateral view with a distinctively curved ventral side towards the apical end and a ridge

running from the embryo towards the apex (arrow in $\mathbf{g - i}$ ). Some grains show fragments of the tuberculate lemma adhering to their dorsal side $(\mathbf{e}, \mathbf{f}, \mathbf{h})$

Grain dimensions of charred Triticoid-types from all three archaeological sites fully overlap (Fig. 6). The new samples from Ganj Dareh yielded some unusually large specimens (ESM 1 Fig. 3), which may in part be explainable by carbonisation (see below). Comparing the grain size ranges of related Triticeae taxa shows that cross-section measurements cannot distinguish between wild einkorn (both one- and two-seeded forms) and Triticoid-types (Fig. 6a), whereas length measurements separated the Triticoid-types from the wild wheats due to their shorter

grains (Fig. 6b). Grains of domesticated wheats from Neolithic sites are on average larger, so size measurements should allow a separation from Triticoid-types. These results confirm that the archaeological Triticoid-type grains represent a distinct species and do not include significant amounts of misidentified wild wheats. However, the large size range of the Ganj Dareh specimens indicates that grain dimension alone can be an ambiguous identification criterion, which is why we use additional morphological criteria to reliably identify the Triticoid-types. 


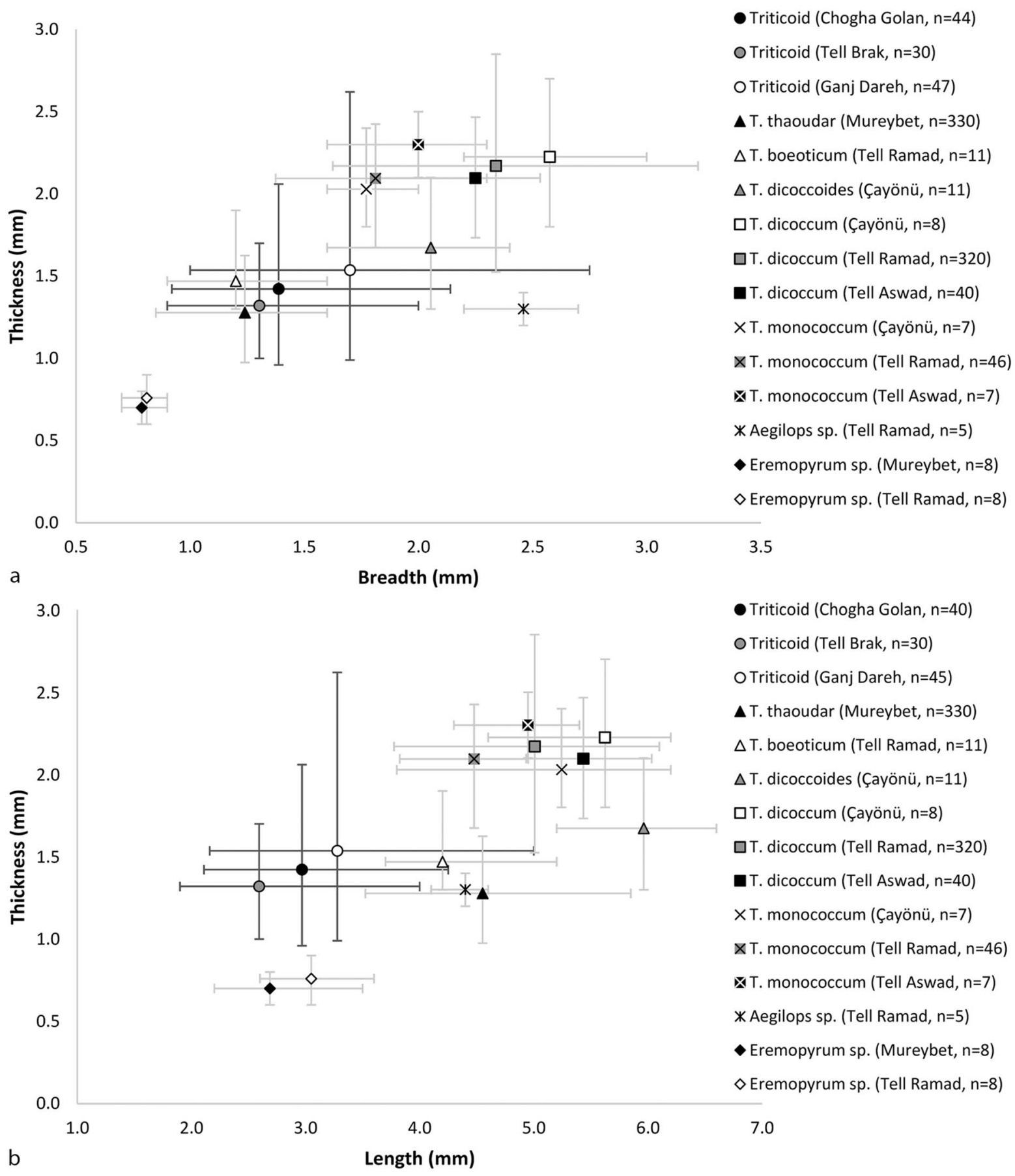

Fig. 6 Mean dimensions and ranges of charred Triticoid-type grains and related Triticeae taxa from Early Neolithic archaeological deposits expressed as breadth by thickness (a) and length by thickness (b);

Triticoid-type grain measurements for Ganj Dareh include those provided from van Zeist et al. (see ESM 1 Fig. 3)

The archaeological specimens are often heavily distorted and show a high morphological variability in grain shape, complicating their identification. Figure 7 shows a compilation of charred Triticoid-type grains from Early Neolithic deposits at Chogha Golan and Ganj Dareh. The specimens from Chogha Golan that have a fragment of the tuberculate lemma preserved on their dorsal surface can be reliably identified, although some of these grains could easily be confused with two-grained einkorn, rye or emmer wheat based on their shape alone. Most grains from Chogha Golan lack an adherent lemma fragment but can still be reliably identified based on their distinctive lateral shape and, in some 


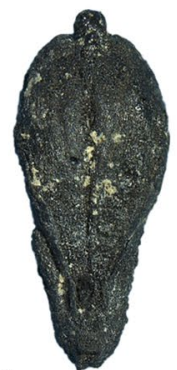

a
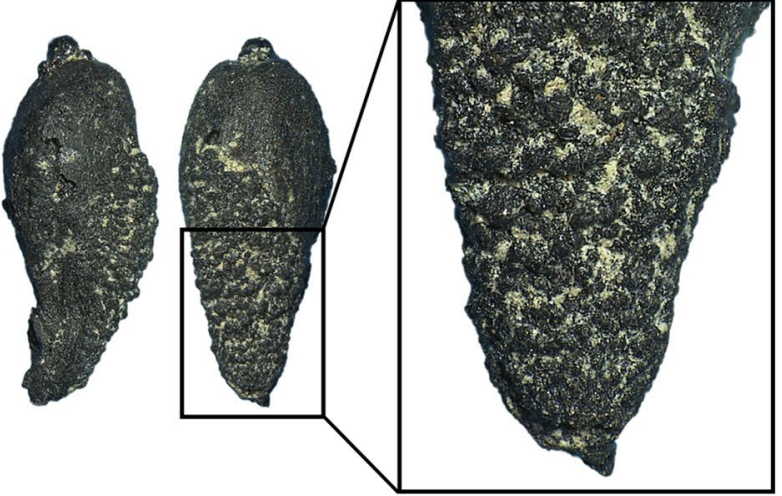
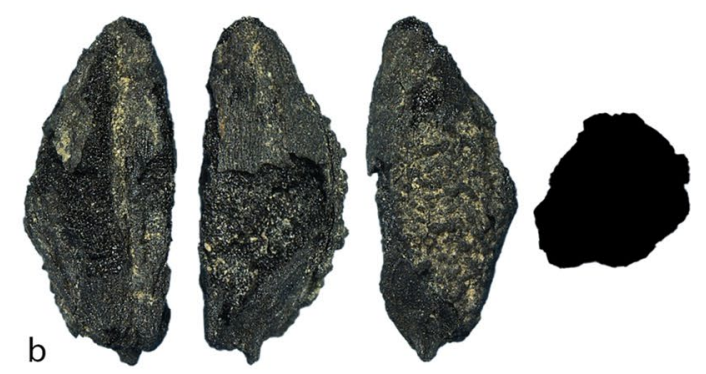

d
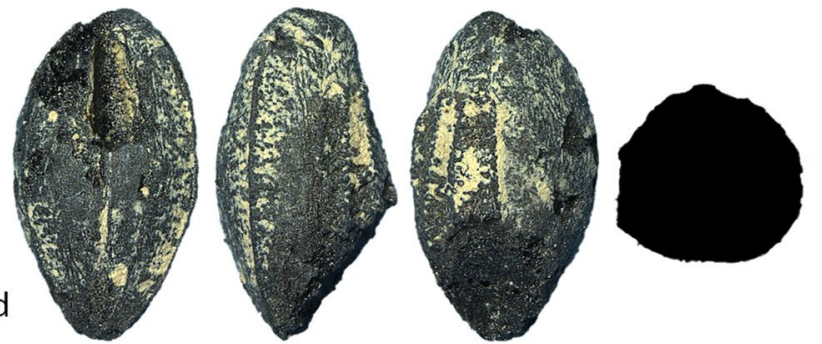

C
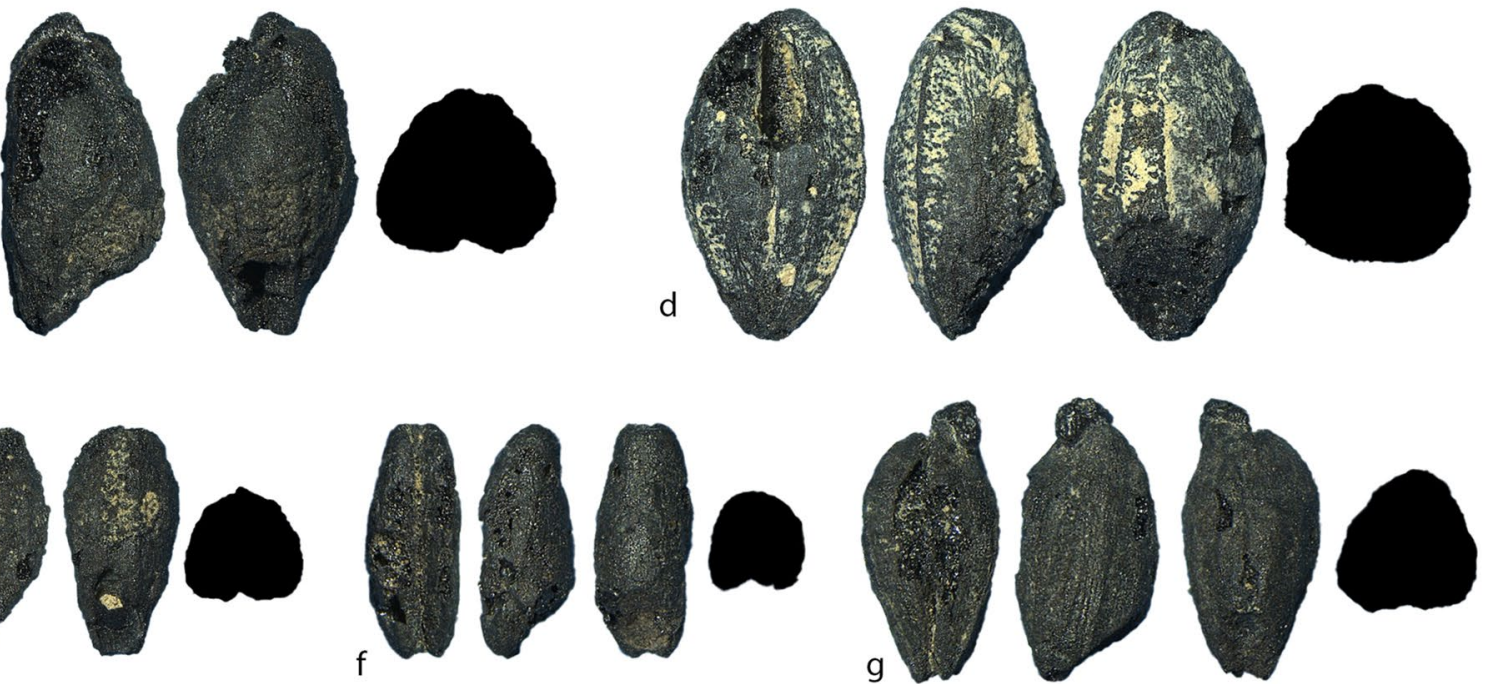

e
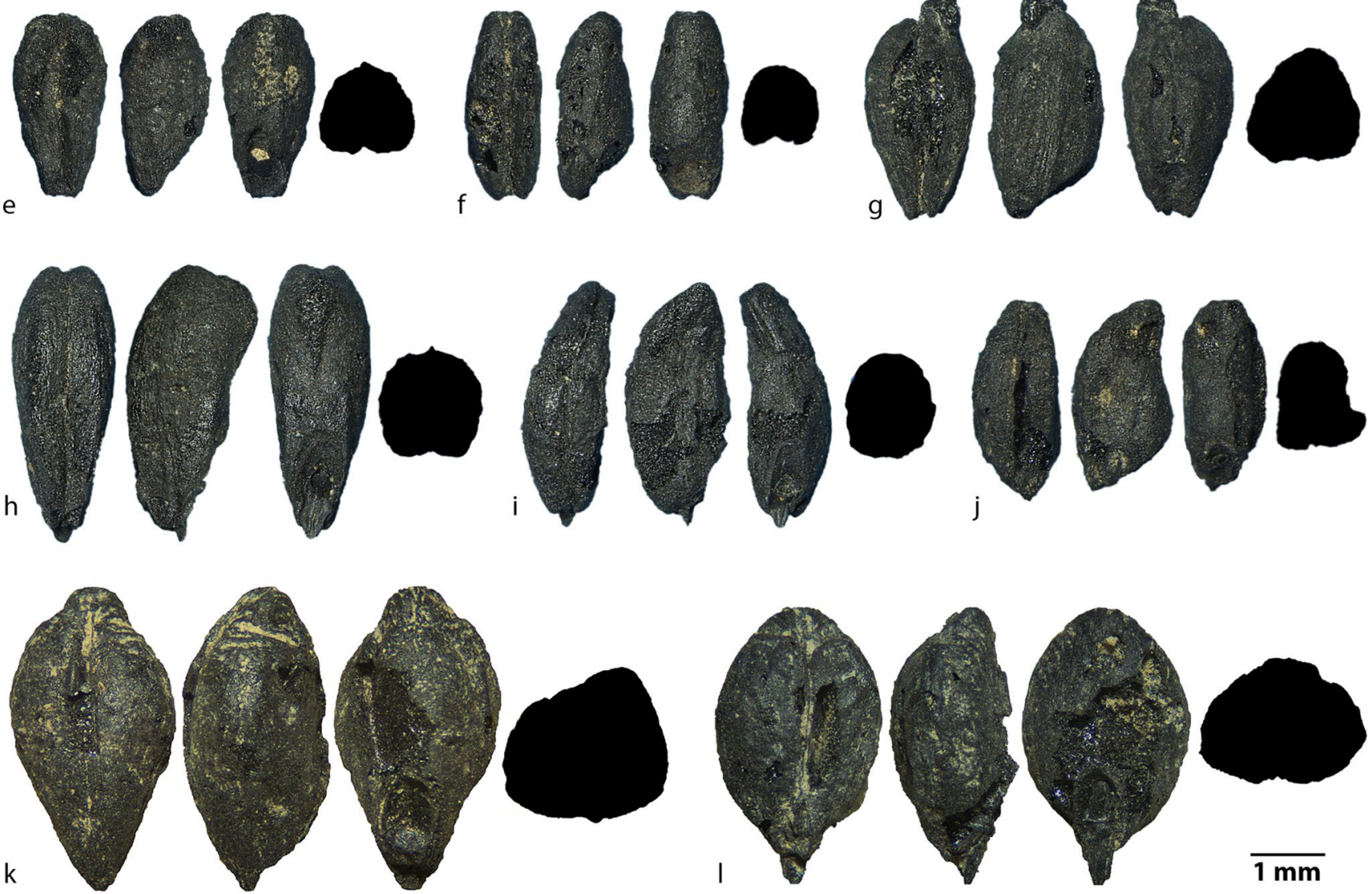

Fig. 7 Carbonised Triticoid-type grains from a-j Chogha Golan and $\mathbf{k}, \mathbf{l}$ Ganj Dareh. Note the variable shape in lateral view with the distinctively curved apical end not always present. Some grains show fragments of the tuberculate lemma adhering to their dorsal and lateral surface $(\mathbf{a}-\mathbf{e})$. Grains without adhering lemma fragments are
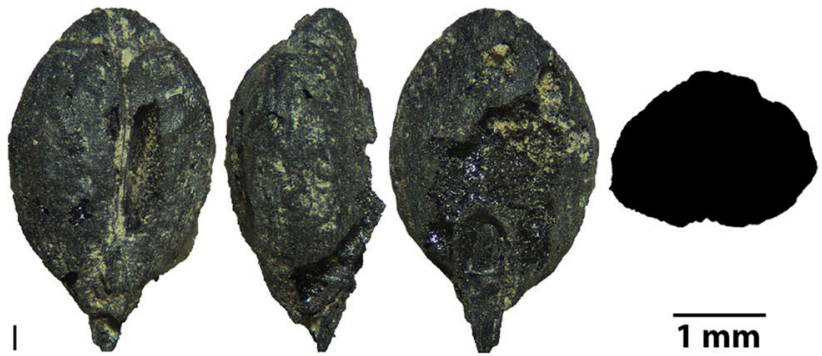

identifiable as $H$. piliferum based on their distinctive shape in lateral view (f, $\mathbf{g}, \mathbf{i}-\mathbf{l})$ and/or their typical lateral ridge $(\mathbf{g}, \mathbf{h})$. Shape alone can resemble grains of two-grained einkorn/rye $(\mathbf{b}, \mathbf{h})$ or emmer wheat $(\mathbf{c})$ 
cases, the visible lateral ridge. The identification of the Triticoid-type grains as $H$. piliferum from samples dating to the Late Bronze Age at Tell Brak is also based on fragments of the tuberculate lemma. Such remains are not present among the specimens from Late Chalcolithic contexts at Tell Brak or from Ganj Dareh, which, however, could be reliably identified based on grain shape in lateral view. We did not reexamine the material from Early Bronze Age samples at Tell Brak (Charles and Bogaard 2001), but personal communication with A. Bogaard and M. Charles, and the fact that Triticoid-type grains occur in both older and younger contexts, makes us confident that $H$. piliferum occurs throughout all occupation phases of the site. We could also not re-examine the grains from M'lefaat, but the description given by the authors and the illustrations of the grains closely match the Triticoid-type grains we analysed. Several of the illustrated grains show the distinctive rhomboid shape in lateral view (Savard et al. 2003, Fig. 3b), which does not occur among charred T. boeoticum or Secale grains (see below). Therefore, we consider it highly likely that $H$. piliferum is present at M'lefaat. Table 1 gives an overview over the sites, phases and dates where Triticoid-type grains now identified as $H$. piliferum are present.

Figure 8 shows SEM photographs of the lemma surface of uncharred modern $H$. piliferum grains and charred Triticoidtype grains from Chogha Golan. The tubercles on the lemma surface are of varying sizes and unevenly distributed. They carry a pointed scale, which is clearly visible in the modern specimens and in some of the archaeological ones. Where this scale is lost, the tubercles have a crater-like appearance, which is still visible in archaeological specimens where most tubercles are eroded. The lemmas with the distinctive tubercles preserved on some archaeological specimens is the most reliable feature to identify the Triticoid-type grains as H. piliferum. Moreover, only very few Triticeae taxa have a tuberculate lemma. We examined one species of every
Triticeae genus in the comparative collection of the Institute of Archaeology at UCL and only found much smaller and evenly scattered tubercles and scales on the lemmas of Aegilops tauschii, Amblyopyrum muticum, Crithopsis delileana and Eremopyrum bonaepartis.

The effects of experimental carbonisation on grain shape revealed three important observations (Fig. 9). First, grains of $\mathrm{H}$. piliferum already showed significant signs of deformation at $260{ }^{\circ} \mathrm{C}$ and fully lost their characteristic shape at $300{ }^{\circ} \mathrm{C}$. None of the grains charred at the maximum temperature retained the distinctively rhomboid shape in lateral view. In contrast, grain shape of $T$. thaoudar was hardly deformed after being charred at $260{ }^{\circ} \mathrm{C}$ and only developed rounded ventral sides at $300{ }^{\circ} \mathrm{C}$. Grains of $S$. vavilovii showed a stronger response with more rounded grains at 260 and $300{ }^{\circ} \mathrm{C}$, but most specimens retained their slender form and blunt apex. Emmer grains showed the most pronounced deformation and became swollen and rounded at $300{ }^{\circ} \mathrm{C}$ but retained their distinctive humped shape in lateral view (ESM 1 Fig. 4). These results suggest that we can reliably identify grains of $H$. piliferum and related Triticeae species charred at temperatures of up to $260{ }^{\circ} \mathrm{C}$, while higher temperatures might complicate a separation of $H$. piliferum grains due to their strong deformation. Second, the effect of charring on grain shape was much more variable for $H$. piliferum than for the other species. H. piliferum grains charred at 260 and $300{ }^{\circ} \mathrm{C}$ included swollen specimens that are almost fully round in dorsal view, as opposed to grains that retained a more slender form. Grains of S. vavilovii and T. thaoudar did not show such a strong puffing effect and their response to heat was less variable. In contrast, charred $T$. dicoccum grains became increasingly swollen at higher temperatures, but this applied to all grains. Third, the percentage of charred Triticoid-type grains with a cracked pericarp through which the endosperm emerges is rather low and ranges between 14.6 (Chogha Golan, Fig. 7a, g, h), 26.7

Table 1 Archaeological sites where Triticoid-type grains were identified, ordered by descending age

\begin{tabular}{lllll}
\hline Site & Period & Dating (cal BC) & Original designation & References \\
\hline Chogha Golan* & EN & $9,700-7,600$ & Triticoid- or Triticum-type & Riehl et al. (2013), Weide et al. (2017, 2018) \\
M'lefaat & EN & $9,500-9,000$ & cf. Triticoid-type & Savard et al. (2003) \\
East Chia Sabz & EN & $8,500-7,600$ & Triticum-type & Riehl et al. (2012) \\
Ganj Dareh** & EN & $8,200-7,800$ & Triticoid-type & van Zeist et al. (1984), Meiklejohn et al. (2017), this paper \\
Tell Brak* & LC & $3,800-3,100$ & Medium grass A & Hald (2008) \\
Tell Bderi & EBA & $2,750-2,350$ & Triticoid-type & van Zeist (2000) \\
Tell Brak & EBA & $2,400-1,950$ & - & Charles and Bogaard (2001) and pers. comm \\
Tell Brak* & LBA & $1,550-1,300$ & - & This paper, McMahon et al. (2007) \\
\hline
\end{tabular}

Note that the identification from M'lefaat needs confirmation

EN Early Neolithic, LC Late Chalcolithic, EBA Early Bronze Age, LBA Late Bronze Age

*Examined as part of the present study

**Grains from new samples 

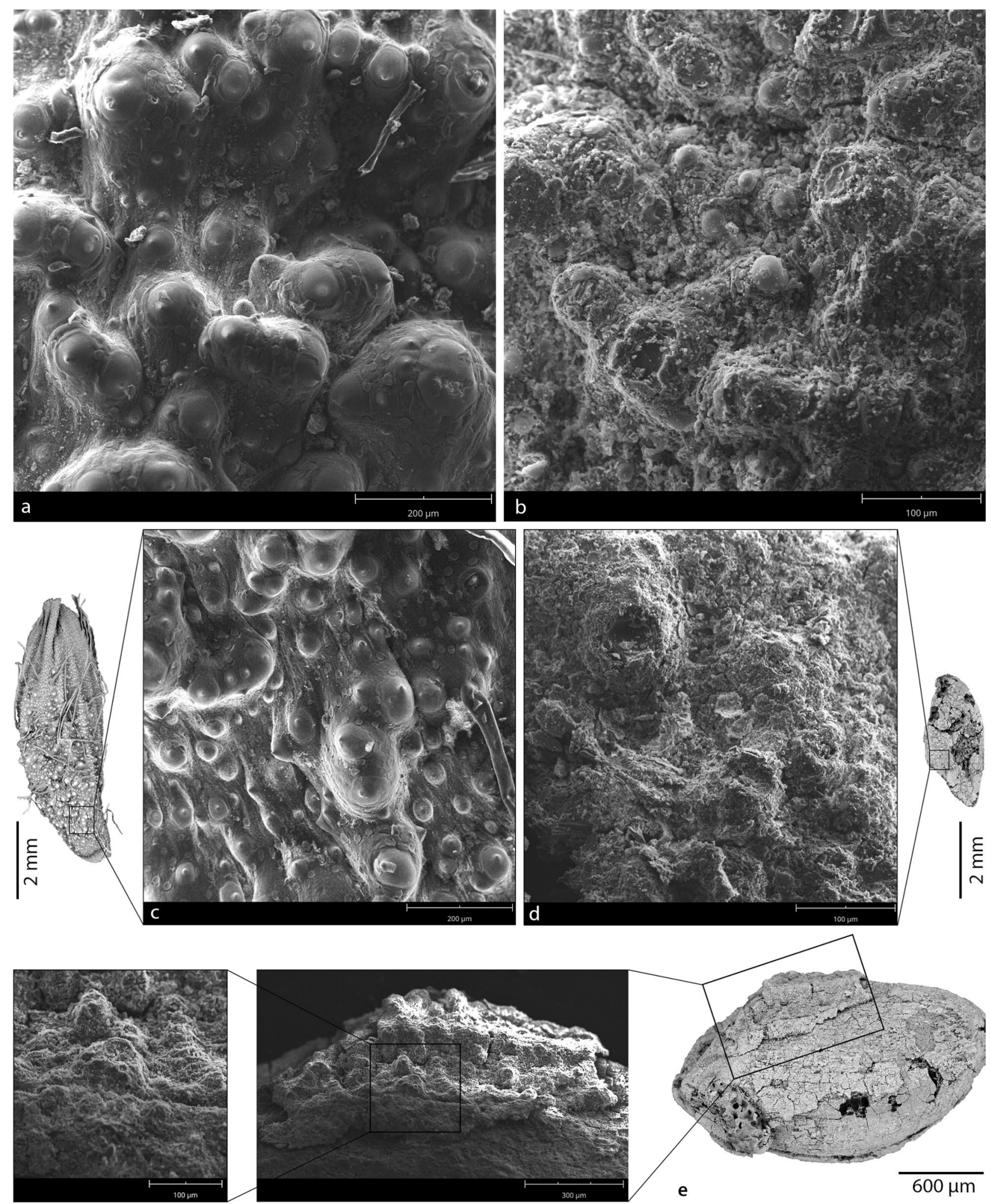

Fig. 8 SEM photographs of the lemma surface structure of modern and ancient $H$. piliferum grains. a Modern lemma showing tubercles with pointed scales of various sizes; $\mathbf{b}$ lemma of a Triticoid-type grain from Chogha Golan showing tubercles of which most lost their scales; c modern hulled $H$. piliferum grain in dorso-lateral view, ca two-thirds of the lemma are tuberculate while the entire lemma is covered with small scales; d, e Triticoid-type grains from Chogha Golan in lateral view showing the characteristic tuberculate lemma 
Fig. 9 Effects of charring for $4 \mathrm{~h}$ at different temperatures on grains of $H$. piliferum $(22,835)$, wild two-grained einkorn $(T$. thaoudar, TRI 17,076) and wild rye (S. vavilovii, R 1126). For every charring run, charred grains are sorted from slender/ less distorted (top) to round/ more distorted (bottom). For information on the accessions see ESM 1 Table 2

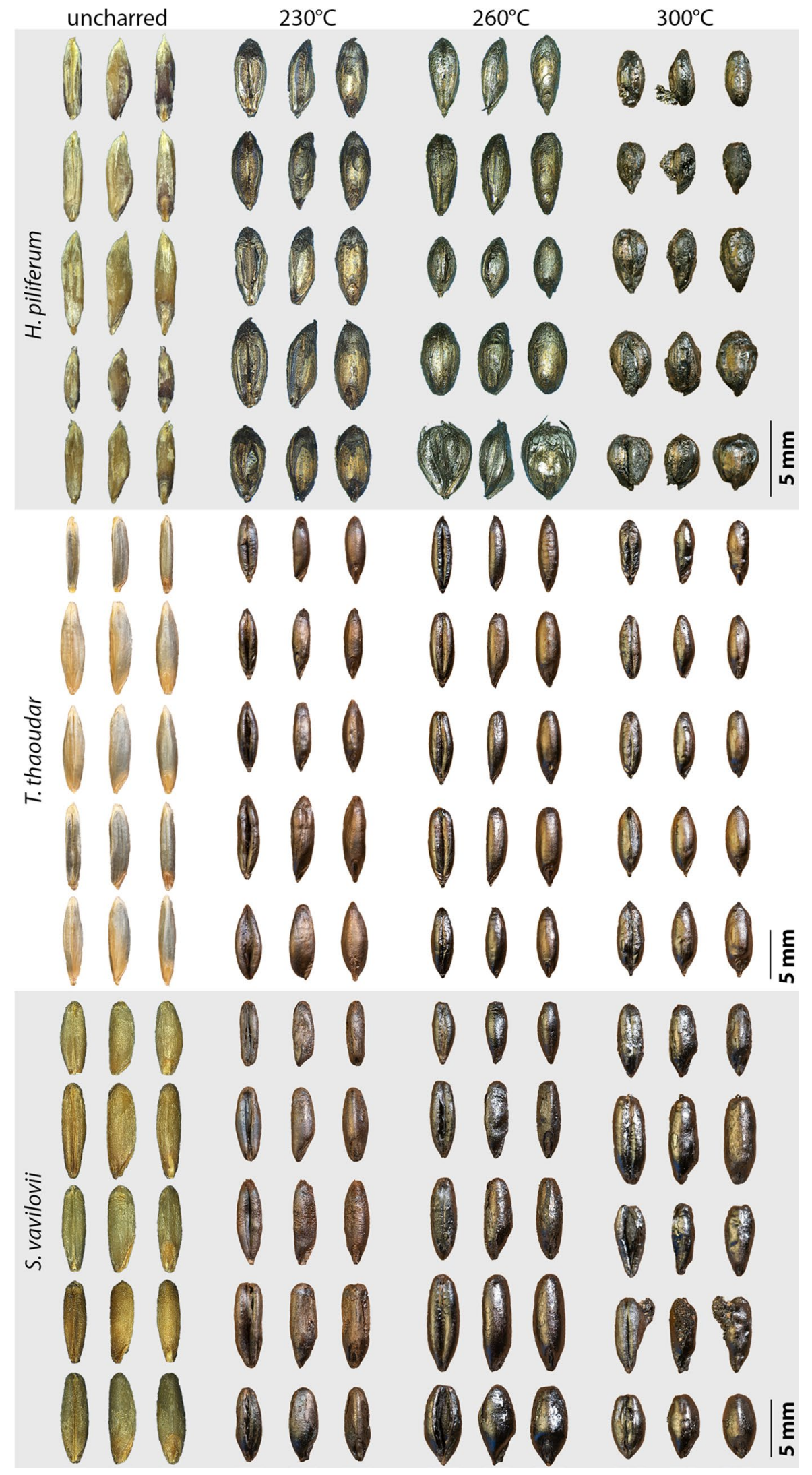


(Tell Brak, LBA) and 30.8\% (Ganj Dareh). In the charring experiment this only happened at 300 but not at $260{ }^{\circ} \mathrm{C}$ for $H$. piliferum grains, so we expect that the charring temperature for most analysed archaeological specimens did not exceeded $260{ }^{\circ} \mathrm{C}$, resulting in well-preserved and identifiable grain assemblages.

\section{Discussion}

\section{Identifying $H$. piliferum grains in archaeobotanical assemblages}

For reliably identifying $H$. piliferum in archaeobotanical assemblages, we need to understand the morphological similarities and differences between charred $H$. piliferum grains and those of emmer wheat, two-grained einkorn and ryes. Confusion between these species obviously exists and presumably contributed to the T. boeoticum/Secale counts at M'lefaat. Grain size measurements alone are a poor tool to separate charred $H$. piliferum grains from other Triticeae species but their shape in lateral view, together with additional morphological characteristics, allow a reliable identification. As described above, the tuberculate lemma is the most reliable identification criterion for $\mathrm{H}$. piliferum grains. When lemma remains are not preserved, the distinct grain shape in lateral view, combined with the presence and direction of the lateral ridge, allows a clear separation from wheats or ryes. Charring temperatures above $260{ }^{\circ} \mathrm{C}$ complicate an identification. These heavily distorted grains, which can be recognised based on pericarp and endosperm features (Charles et al. 2015), should be omitted from the identification process if they do not show a lemma fragment.

Except for wild barley, Hordeum spontaneum, populations of wild cereal progenitors were very scarce if not regionally absent from the eastern arc of the Fertile Crescent during the Early Holocene, which could have been an important factor in shaping local resource choices and different socio-economic developments (Arranz-Otaegui et al. 2016; Weide et al. 2018; Whitlam et al. 2018). The only numerous records for wild wheats or ryes during this period currently derive from Qermez Dere and M'lefaat (Savard et al. 2006). However, if Triticoid-type grains are included in the counts from at least M'lefaat, then the significance of this category and the presence of wild wheat or rye populations in the Tigris basin becomes somewhat ambiguous. During the same time, both taxa were frequently exploited and possibly taken into cultivation in the upper Euphrates basin (Willcox et al. 2008, 2009), so their presence but different treatment a few hundred $\mathrm{km}$ further east would be of high socio-economic significance. We therefore suggest that Early Holocene records of wild einkorn or ryes in the eastern arc of the Fertile Crescent would benefit from re-visiting and confirmation.

\section{The ecological implications of $\boldsymbol{H}$. piliferum in prehistoric contexts}

Although $H$. piliferum has a large modern distribution range, stretching from the northern Negev and Judean deserts in Palestine to the highlands of central Asia, the only prehistoric records are known from between northern Mesopotamia and the Zagros Mountains. At least for the Levant this should not reflect a bias in analysed archaeobotanical assemblages, particularly as W. van Zeist, who first described the Triticoid-type grains, also extensively worked in this region. This does not prove the absence of $H$. piliferum populations west of the Euphrates for the early and mid-Holocene but may be an indicator for its absence in crop harvests, which we will discuss further below. Another explanation for the absence of Triticoid grains from archaeobotanical assemblages beyond northern Mesopotamia and the Zagros Mountains could be that the modern populations in the Levant and central Asia are of a more recent weedy origin. The fact that segetal habitats from which $H$. piliferum was collected during the 20th century also accumulate in northern Mesopotamia and the Zagros Mountains speaks against this possibility. However, only evidence from population genetics could rule out this scenario, as highlighted by recent DNA studies that demonstrate an anthropogenic movement of wild emmer populations out of the southern Levant and across the entire Fertile Crescent since the Early Neolithic (Civáň et al. 2013; Oliveira et al. 2020).

Can the presence of $H$. piliferum in prehistoric assemblages give insights into the vegetation units surrounding these sites? The species is often described as a ruderal highly adapted to disturbed habitats, so it may generally be an indicator for disturbance. However, we do not learn much from this label, as annual species and their reproductive strategies are adapted to various kinds of disturbances in the landscape including long summer droughts, seasonal fires, grazing and human-related disturbances such as ploughing (Grime 1977). Which exact disturbances favour H. piliferum in different situations, as many other annuals and short-lived perennials, may therefore vary. The ecological studies in which the species was recorded demonstrate its occurrence in relatively dry steppes and mesic woodlands but remain ambiguous regarding its adaptation to herbivory. However, its ability to quickly colonise gaps (ruderal habitats), its low height and short life cycle should make it well adapted to grazing as opposed to larger perennials (Lavorel et al. 1997; Bullock et al. 2001). Since we expect various disturbances in the area surrounding human settlements, which represents an anthropogenic disturbance by itself, floras dominated by annuals including $H$. piliferum may develop in proximity to 
any prehistoric settlement in southwest Asia. Moreover, we did not find a correlation between maximum plant height and altitude, suggesting that $H$. piliferum finds equally suitable growing conditions in a wide range of different vegetation zones. Therefore, rather than treating the species as an ecological indicator, we must focus on its taphonomy and ask how Triticoid-type grains became incorporated into charred archaeobotanical assemblages and which implications this has for reconstructing subsistence practices. Possible routes of entry include the collection of animal dung as fuel or construction materials, $H$. piliferum being harvested as an arable weed, and its deliberate collection for dietary or other purposes.

Due to the size of the grains and the lack of a hard seed coat or enclosure (Valamoti and Charles 2005; Wallace and Charles 2013) we can regard H. piliferum grains as poorly adapted to survive ruminant digestion. The use of dung as fuel or construction material is therefore unlikely to be the main route of entry into archaeological deposits.

The species is known to thrive in arable fields, so we can principally expect it to represent an arable weed at prehistoric farming sites as well. Fruit and seed size of annuals can rapidly respond to enhanced growing conditions, as e.g. K. Hammer demonstrated for Papaver setigerum (Hammer 1984). This poses the question whether an increased seed size could also be a feature of annuals growing in more productive habitats such as manured and/or irrigated fields, especially as the cultivated $H$. piliferum specimens were significantly taller than the collected plants. However, specimens collected from arable fields were not on average taller than plants from other habitats, indicating that at least these sampled fields did not provide enhanced growing conditions. Moreover, the cultivated population did not produce larger grains than the collected plants. Mean grain thickness was even lower for the cultivars, due to numerous 'flat' specimens, a phenomenon which we cannot explain with the available data. The fact that variability in grain length was reduced in the cultivated population may simply indicate more uniform growing conditions under cultivation as opposed to the specimens collected from a variety of habitats. We must therefore conclude that grain size would be a poor indicator for reconstructing growing conditions or potential prehistoric habitats of $H$. piliferum.

The ability of $H$. piliferum to increase vegetative growth under cultivation was probably due to increased nutrient levels and the release from competition. Both factors allow annual plants to accumulate more biomass and increase their reproductive output (Sugiyama and Bazzaz 1998; Neytcheva and Aarssen 2008; Lutman et al. 2011). Generally, the relationship between vegetative size and seed production in monocarpic plants is allometric, which means that larger plants produce a higher total seed mass (Shipley and Dion 1992; Aarssen and Jordan 2001; Weiner et al. 2009).
However, grain size alone is a poor indicator for the total seed mass, as larger monocarpic plants also tend to produce more seeds. We can therefore assume that the cultivated $H$. piliferum specimens achieved a higher reproductive output, but by increasing the number of tillers and spikes (cf. ESM 1 Fig. 1), and hence grains, not by developing larger individual grains.

Independently from the above considerations, the archaeobotanical analyses from Tell Bderi and Tell Brak clearly attest the state of $H$. piliferum as an arable weed in crop fields of Late Chalcolithic and Early Bronze Age urban centres in northern Mesopotamia. In her assessment of the Late Chalcolithic archaeobotanical material from Tell Brak, Hald (2008) concluded that the plant remains from the studied contexts predominantly represent crops and their processing by-products. While most samples were of mixed origin, some samples represent either discarded glume wheat chaff, stored grains of two-row hulled barley or stored flax seeds. The Triticoid-type grains were analysed as part of a larger complex of medium-sized grasses, which predominantly occur in samples of mixed origin. These do unfortunately not allow to reconstruct with which crops $H$. piliferum was harvested. More informative is a sample from Tell Bderi, representing an uncleaned two-row hulled barley store (van Zeist 1999/2000). Only three Triticoid-type grains were identified in this storage sample along with hundreds of other Poaceae grains and more than 1,500 Aegilops sp. grains and spikelet bases. This relative scarcity of $H$. piliferum grains, which only occur in one other sample from Tell Bderi, suggests that it was not regularly brought into the site with the barley harvest and that the species does not mimic cereal crops as e.g. Aegilops spp. or other crop progenitors do (Hammer 1980; Harlan 1982). To harvest $H$. piliferum as a weed, the harvesting height would need to be very low, between 10 and $20 \mathrm{~cm}$ above the ground, a fact that possibly discriminates against $H$. piliferum in many situations if the straw is not systematically harvested. However, harvesting heights as low as $10-15 \mathrm{~cm}$ were documented ethnographically from southern Mesopotamia (Charles 1990). Its presence, although in low numbers, at Tell Bderi and Tell Brak may therefore indicate such a low harvesting height, which Hald (2008) suggested as well. Nearly all samples from Late Chalcolithic Tell Brak contain small weed species $(<30 \mathrm{~cm})$, some with considerable amounts of between 40 and $80 \%$ of all weeds. Culm nodes were fairly common in the samples as well, which may also indicate relatively low harvesting heights (Hillman 1981). Interestingly, the two samples from Tell Bderi in which Triticoid-type grains occur contained the highest number of culm fragments among all samples from this site, which may support the interpretation that higher numbers of culm nodes indicate low harvesting heights.

In term of its ecological implications for reconstructing ancient cultivation regimes based on functional attributes, 
$H$. piliferum represents a low-growing, early and shortflowering winter annual that is well adapted to dry soil conditions. All these traits correspond to rather extensive, autumn-sown cultivation regimes that do not rely on heavy manuring or systematic irrigation (Jones et al. 2010 and references therein). The functional ecological data of the weed floras from Late Chalcolithic and Early Bonze Age Tell Brak, together with crop isotope evidence, indicate such an extensive, 'low-input' cultivation regime, although variability of course exists (Hald 2008; Bogaard et al. 2018). In this sense, the presence of $H$. piliferum in the weed floras of upper Mesopotamian urban centres may predominantly be related to their relatively extensive cereal cultivation systems. Such extensive systems slowly developed with the urbanisation of the region (Styring et al. 2017) and the absence of $H$. piliferum in weed assemblages from earlier northern Mesopotamian sites may in part be related to the prevalence of more labour-intensive and productive cultivation regimes. However, we cannot fully rule out that difficulties in its identification contributed to this pattern.

\section{The role of $\boldsymbol{H}$. piliferum in Early Neolithic subsistence practices}

In contrast to Chalcolithic and Bronze Age towns, the taphonomy of $H$. piliferum at Early Neolithic sites seems to be different. Weide et al. (2018) argued that Early Neolithic communities in the eastern arc of the Fertile Crescent until ca $8000 \mathrm{cal}$ BC exploited a complex of large to-medium seeded wild grasses and did not heavily focus on wild progenitor species, as opposed to contemporary groups in the upper Euphrates basin and the southern Levant (Colledge 2001; Willcox et al. 2008; Arranz-Otaegui et al. 2016). This hypothesis is supported by archaeobotanical data from virtually all sites in this region where comprehensive archaeobotanical analyses were conducted, including Qermez Dere and M'lefaat in the upper Tigris basin (Savard et al. 2003, 2006) and Chogha Golan, East Chia Sabz and Sheikh-e Abad in the central Zagros (Riehl et al. 2012; Weide et al. 2018; Whitlam et al. 2018). Significantly, Triticoid-type grains were reported from all these sites except for Qermez Dere and Sheikh-e Abad (the absence of this grain type at Sheikhe Abad was confirmed with J. Whitlam). H. piliferum was part of this complex of wild grasses, which among others included species of Aegilops, Avena, Hordeum, Stipa, Bromus and Piptatherum. Their grains were regularly and over a considerable amount of time (almost 2,000 years) brought into settlements. As discussed, H. piliferum is rather short, also compared to the other exploited grasses, and is thus not very abundant as an arable weed in crop assemblages at younger farming sites. Its accumulated occurrence in Early Neolithic contexts therefore supports the hypothesis that $H$. piliferum and the other wild grasses were deliberately harvested. As a working hypothesis we suggest the grains or grain products of these species were consumed, but it is challenging to explain their exact utilisation and whether grassland resources were managed. However, in ecological terms most of these species are well adapted to colonise disturbed areas around settlements, which may have facilitated their long-term exploitation. These findings further add to the multi-regional character of Early Holocene subsistence strategies throughout the Fertile Crescent, highlighting that the oldest Neolithic communities in the Tigris basin and Zagros Mountains relied on a high diversity of grassland resources without depending on the wild progenitors of wheats and barley.

\section{Conclusions}

Thanks to the careful examination of the archaeobotanical assemblage from Ganj Dareh, W. van Zeist and his colleagues recognised and described the Triticoid-type grains that obviously belonged to a species complex including wild progenitors of the Near Eastern founder crops. With the identification of these grains as $H$. piliferum we can clarify some confusion about this morphotype, which has been thought to represent an extinct Triticeae taxon or several different species due to its large morphological variability. We are now able to identify this species more reliably in archaeobotanical assemblages and can separate it from its close cereal relatives. Triticoid-type grains likely contributed to wheat and rye counts of Early Neolithic assemblages, possibly inducing a bias in the ancient distribution of largeseeded wild cereals and their Early Holocene exploitation patterns. Although the exact role of H. piliferum in Early Neolithic subsistence strategies is difficult to reconstruct, we assume it was part of a complex of wild grasses deliberately harvested by groups between the upper Tigris basin and the central Zagros Mountains. With the subsequent emergence of cereal farming, the species found an additional suitable habitat in arable fields, although its ability to reproduce in crop fields may depend on the cultivation regime. Therefore, as a low-growing, early/short-flowering and drought-resistant winter annual, it has the potential to contribute to our understanding of past crop husbandry practices, including sowing time, harvesting height and cultivation intensity.

Acknowledgements With this study we want to deeply acknowledge the work of Willem van Zeist (1924-2016), whose outstanding contributions to the Archaeobotany of the ancient Near East continue to shape current approaches and research directions. We would further like to thank Amy Bogaard for helpful comments on a first draft of the manuscript and Simone Riehl for her work on the Archaeobotany of Chogha Golan, which again drew attention to the Triticoid-type grains. Many thanks to Dorian Fuller, who accommodated us for an afternoon to examine Triticeae species from the UCL comparative collection. A. Weide would like to express his warmest thanks to his colleagues Hagar 
Leschner, Yoel Melamed, Tamar Avin-Wittenberg and Ehud Weiss for their help and support during the field research, which represents the basis for the present article. The same appreciation goes to Mark Nesbitt, who gave helpful input into the development of the study and offered valuable advice during the work in the herbarium at Royal Botanic Gardens, Kew.

Open Access This article is licensed under a Creative Commons Attribution 4.0 International License, which permits use, sharing, adaptation, distribution and reproduction in any medium or format, as long as you give appropriate credit to the original author(s) and the source, provide a link to the Creative Commons licence, and indicate if changes were made. The images or other third party material in this article are included in the article's Creative Commons licence, unless indicated otherwise in a credit line to the material. If material is not included in the article's Creative Commons licence and your intended use is not permitted by statutory regulation or exceeds the permitted use, you will need to obtain permission directly from the copyright holder. To view a copy of this licence, visit http://creativecommons.org/licenses/by/4.0/.

\section{References}

Aarssen LW, Jordan C (2001) Between-species patterns of covariation in plant size, seed size and fecundity in monocarpic herbs. Écoscience 8:471-477. https://doi.org/10.1080/11956860.2001.11682 677

Abu-Zanat M, Osman A, Tabba'a M (1998) Seed bank assessment on heavily grazed Mediterranean grasslands in Jordan. Dirasat 25:195-202

Arranz-Otaegui A, Colledge S, Zapata L, Teira-Mayolini LC, Ibáñez JJ (2016) Regional diversity on the timing for the initial appearance of cereal cultivation and domestication in southwest Asia. Proc Natl Acad Sci USA 113:14001-14006. https://doi.org/10.1073/ pnas. 1612797113

Bogaard A, Styring A, Ater M et al (2018) From traditional farming in morocco to early urban agroecology in northern mesopotamia: combining present-day arable weed surveys and crop isotope analysis to reconstruct past agrosystems in (semi-)arid regions. Environ Archaeol 23:303-322. https://doi.org/10.1080/14614 103.2016.1261217

Bor NL (1970) Gramineae. In: Rechinger KH (ed) Flora Iranica, vol 70. Akademische Druck- und Verlagsanstalt, Graz

Bullock JM, Franklin J, Stevenson MJ, Silvertown J, Coulson SJ, Gregory SJ, Tofts R (2001) A plant trait analysis of responses to grazing in a long-term experiment. J Appl Ecol 38:253-267. https ://doi.org/10.1046/j.1365-2664.2001.00599.x

Charles MP (1990) Traditional crop husbandry in Southern Iraq (19001960 AD). Bull Sumer Agric 5:47-64

Charles M, Bogaard A (2001) Third-millennium BC charred plant remains from Tell Brak. In: Oates D, Oates J, McDonald $\mathrm{H}$ (eds) Excavations at Tell Brak, Vol 2: Nagar in the Third Millennium BC. McDonald Institute for Archaeological Research and the British School of Archaeology in Iraq, Cambridge, pp 301-326

Charles M, Forster E, Wallace M, Jones G (2015) "Nor ever lightning char thy grain": establishing archaeologically relevant charring conditions and their effect on glume wheat grain morphology. STAR: Sci Technol Archaeol Res 1:1-6. https://doi. org/10.1179/2054892315Y.0000000008

Civáň P, Ivaničová Z, Brown TA (2013) Reticulated origin of domesticated emmer wheat supports a dynamic model for the emergence of agriculture in the fertile crescent. PLoS ONE 8:e81955. https ://doi.org/10.1371/journal.pone.0081955
Colledge S (2001) Plant exploitation on Epipalaeolithic and early Neolithic sites in the Levant. BAR International Series 986. British Archaeological Reports, Oxford

Darabi H, Richter T, Mortensen P (2019) Neolithization process in the central Zagros. Doc Praehist 46:44-56. https://doi.org/10.4312/ dp. 46.3

Escobar JS, Scornavacca C, Cenci A et al (2011) Multigenic phylogeny and analysis of tree incongruences in Triticeae (Poaceae). BMC Evol Biol 11:181. https://doi.org/10.1186/1471-2148-11-181

Feinbrun-Dothan N (1986) Alismataceae to orchidaceae. In: Zohary M, Feinbrun-Dothan N (eds) Flora palaestina, vol 4. The Israel Academy of Sciences and Humanities, Jerusalem

Grime JP (1977) Evidence for the existence of three primary strategies in plants and its relevance to ecological and evolutionary theory. Am Nat 111:1169-1194. https://doi.org/10.1086/283244

Hald MM (2008) A thousand years of farming: Late Chalcolithic agricultural practices at Tell Brak in Northern Mesopotamia. BAR International Series 1880. British Archaeological Reports, Oxford

Hammer K (1980) Vorarbeiten zur monographischen Darstellung von Wildpflanzensortimenten: Aegilops L. Die Kulturpflanze 28:33180. https://doi.org/10.1007/bf02014641

Hammer K (1984) Das Domestikationssyndrom. Die Kult 32:11-34. https://doi.org/10.1007/BF02098682

Harlan JR (1982) Relationships between weeds and crops. In: Holzner W, Numata M (eds) Biology and ecology of weeds. Springer, Dordrecht, pp 91-96. https://doi. org/10.1007/978-94-017-0916-3_8

Heydari M, Poorbabaei H, Rostami T, Begim Faghir M, Salehi A, Ostad Hashmei R (2013) Plant species in Oak (Quercus brantii Lindl.) understory and their relationship with physical and chemical properties of soil in different altitude classes in the Arghvan valley protected area. Iran Casp J Environ Sci 11:97-110

Hijmans RJ, Cameron SE, Parra JL, Jones PG, Jarvis A (2005) Very high resolution interpolated climate surfaces for global land areas. Int J Climatol 25:1965-1978

Hillman GC (1981) Reconstructing crop husbandry practices from charred remains of crops. In: Mercer R (ed) Farming practice in British prehistory. Edinburgh University Press, Edinburgh, pp 123-162

Hodge CD, Wang H, Sun G (2010) Phylogenetic analysis of the maternal genome of tetraploid StStYY Elymus (Triticeae: Poaceae) species and the monogenomic Triticeae based on rps 16 sequence data. Plant Sci 178:463-468. https://doi.org/10.1016/j.plant sci.2010.03.002

Jones G, Charles M, Bogaard A, Hodgson J (2010) Crops and weeds: the role of weed functional ecology in the identification of crop husbandry methods. J Archaeol Sci 37:70-77. https://doi. org/10.1016/j.jas.2009.08.017

Kenéz Á, Malatinszky Á, Pető Á (2014) The first archaeobotanical evidence of Dasypyrum villosum in Hungary: an archaeophyte weed or a native grass? Veget Hist Archaeobot 23:841-849. https ://doi.org/10.1007/s00334-014-0468-9

Lavorel S, McIntyre S, Landsberg J, Forbes TDA (1997) Plant functional classifications: from general groups to specific groups based on response to disturbance. Trends Ecol Evol 12:474-478. https ://doi.org/10.1016/S0169-5347(97)01219-6

Lutman PJW, Wright KJ, Berry K, Freeman SE, Tatnell L (2011) Estimation of seed production by Myosotis arvensis, Veronica hederifolia, Veronica persica and Viola arvensis under different competitive conditions. Weed Res 51:499-507. https://doi.org/1 0.1111/j.1365-3180.2011.00863.x

Malekpour B (1975) Ecology of range resources of the central province of Iran. University of Wyoming, Laramie

McMahon A, Oates J et al (2007) Excavations at Tell Brak 2006-2007. Iraq 69:145-171. https://doi.org/10.1017/S0021088900001091 
Meiklejohn C, Merrett DC, Reich D, Pinhasi R (2017) Direct dating of human skeletal material from Ganj Dareh, Early Neolithic of the Iranian Zagros. J Archaeol Sci: Rep 12:165-172

Neytcheva MS, Aarssen LW (2008) More plant biomass results in more offspring production in annuals, or does it? Oikos 117:1298-1307. https://doi.org/10.1111/j.0030-1299.2008.16695.x

Oliveira HR, Jacocks L, Czajkowska BI, Kennedy SL, Brown TA (2020) Multiregional origins of the domesticated tetraploid wheats. PLoS ONE 15:e0227148. https://doi.org/10.1371/journ al.pone. 0227148

Pourbabae H, Rahimi V, Adel MN (2014) Effects of drought on plant species diversity and productivity in the oak forests of Western Iran. Ecol Balk 6:61-71

Riehl S, Benz M, Conard NJ, Darabi H, Deckers K, Nashli HF, ZeidiKulehparcheh M (2012) Plant use in three Pre-Pottery Neolithic sites of the northern and eastern Fertile Crescent: a preliminary report. Veget Hist Archaeobot 21:95-106. https://doi.org/10.1007/ s00334-011-0318-y

Riehl S, Zeidi M, Conard NJ (2013) Emergence of agriculture in the foothills of the Zagros mountains of Iran. Science 341:65-67. https://doi.org/10.1126/science.1236743

Russi L, Cocks PS, Roberts EH (1992) Seed bank dynamics in a Mediterranean grassland. J Appl Ecol 29:763-771. https://doi. org/10.2307/2404486

Sakamoto S (1974) Intergeneric hybridization among three species of Heteranthelium, Eremopyrum and Hordeum, and its significance for the genetic relationships within the tribe Triticeae. New Phytol 73:341-350

Savard M, Nesbitt M, Gale R (2003) Archaeobotanical evidence for early Neolithic diet and subsistence at M'lefaat (Iraq). Paléorient 29:93-106

Savard M, Nesbitt M, Jones MK (2006) The role of wild grasses in subsistence and sedentism: new evidence from the northern Fertile Crescent. World Archaeol 38:179-196. https://doi. org/10.1080/00438240600689016

Schneider CA, Rasband WS, Eliceiri KW (2012) NIH Image to ImageJ: 25 years of image analysis. Nat Methods 9:671-675. https://doi. org/10.1038/nmeth.2089

Shipley B, Dion J (1992) The allometry of seed production in herbaceous angiosperms. Am Nat 139:467-483. https://doi. org/10.1086/285339

Styring AK, Charles M, Fantone F et al (2017) Isotope evidence for agricultural extensification reveals how the world's first cities were fed. Nat Plants 3:17076. https://doi.org/10.1038/nplan ts. 2017.76

Sugiyama S, Bazzaz FA (1998) Size dependence of reproductive allocation: the influence of resource availability, competition and genetic identity. Funct Ecol 12:280-288. https://doi.org/10.104 6/j.1365-2435.1998.00187.x

Valamoti SM, Charles M (2005) Distinguishing food from fodder through the study of charred plant remains: an experimental approach to dung-derived chaff. Veget Hist Archaeobot 14:528533. https://doi.org/10.1007/s00334-005-0090-y
Van Zeist W, Bakker-Heeres JAH (1982) Archaeobotanical studies in the Levant: I. Neolithic sites in the Damascus basin: Aswad, Ghoraife, Ramad. Palaeohistoria 24:165-256

Van Zeist W, Bakker-Heeres JAH (1984) Archaeobotanical studies in the Levant: 3. Late-Palaeolithic Mureybit. Palaeohistoria 26:171-199

Van Zeist W, Smith PEL, Palfenier-Vegter RM, Suwijn M, Casparie WA (1984) An archaeobotanical study of Ganj Dareh Tepe. Iran Palaeohist 26:201-224

Van Zeist W, de Roller GJ (1991/1992) The plant husbandry of aceramic Çayönü, SE Turkey. Palaeohistoria 33/34:65-96

Van Zeist W (1999/2000) Third to first millennium BC plant cultivation on the Khabur, North-Eastern Syria. Paleohistoria 41/42:111-125

Wallace M, Charles M (2013) What goes in does not always come out: the impact of the ruminant digestive system of sheep on plant material, and its importance for the interpretation of dung-derived archaeobotanical assemblages. Environ Archaeol 18:18-30. https ://doi.org/10.1179/1461410313Z.00000000022

Weide A, Riehl S, Zeidi M, Conard NJ (2017) Reconstructing subsistence practices: taphonomic constraints and the interpretation of wild plant remains at aceramic Neolithic Chogha Golan, Iran. Veget Hist Archaeobot 26:487-504. https://doi.org/10.1007/s0033 4-017-0607-1

Weide A, Riehl S, Zeidi M, Conard NJ (2018) A systematic review of wild grass exploitation in relation to emerging cereal cultivation throughout the epipalaeolithic and aceramic Neolithic of the Fertile Crescent. PLoS ONE 13:e0189811. https://doi.org/10.1371/ journal.pone.0189811

Weiner J, Campbell LG, Pino J, Echarte L (2009) The allometry of reproduction within plant populations. J Ecol 97:1220-1233. https ://doi.org/10.1111/j.1365-2745.2009.01559.x

Whitlam J, Bogaard A, Matthews R, Matthews W, Mohammadifar Y, Ilkhani H, Charles M (2018) Pre-agricultural plant management in the uplands of the central Zagros: the archaeobotanical evidence from Sheikh-e Abad. Veget Hist Archaeobot 27:817-831. https:// doi.org/10.1007/s00334-018-0675-x

Willcox G, Fornite S, Herveux L (2008) Early Holocene cultivation before domestication in northern Syria. Veget Hist Archaeobot 17:313-325. https://doi.org/10.1007/s00334-007-0121-y

Willcox G, Buxo R, Herveux L (2009) Late Pleistocene and early Holocene climate and the beginnings of cultivation in northern Syria. Holocene 19:151-158. https://doi.org/10.1177/0959683608 098961

World Checklist of Selected Plant Families (2020) Facilitated by the Royal Botanic Gardens, Kew. http://wcsp.science.kew.org. Accessed 27 Mar 2020

Publisher's Note Springer Nature remains neutral with regard to jurisdictional claims in published maps and institutional affiliations. 